\title{
Decreased Serum Insulin-like Growth Factor-I Associated with Growth Failure in Newborn Lambs with Experimental Cyanotic Heart Disease
}

\author{
Daniel Bernstein, Jeffrey R. Jasper, Ron G. Rosenfeld, and Raymond L. Hintz
}

Department of Pediatrics, Stanford University, Stanford, California 94305

\begin{abstract}
To determine whether chronic hypoxemia results in alterations in endocrine function that may contribute to growth failure, we measured growth hormone (GH), somatomedins (insulin-like growth factors I and II, IGF-I and IGF-2), hepatic growth hormone receptors, and circulating IGF-binding proteins IGFBP-3 and IGFBP-2 in 12 newborn lambs with surgically created pulmonic stenosis and atrial septal defect, and in 10 controls. During chronic hypoxemia (oxygen saturation of 60-74\% for $2 \mathrm{wk}$ ), weight gain was $60 \%$ of control (hypoxemic, $135 \pm 20$ vs. control, $216 \pm 26 \mathrm{~g} / \mathrm{d}, P<0.02$ ). IGF-I was decreased by $43 \%$ (hypoxemic 253.6 \pm 29.3 SE vs. control $448.0 \pm 75.5 \mathrm{ng} / \mathrm{ml}, P$ $=0.01)$, whereas $\mathrm{GH}$ was unchanged $(19.9 \pm 5.1$ vs. $11.9 \pm 3.0$ $\mathrm{ng} / \mathrm{ml}$, NS). The increase in IGF-1 was associated with a decrease in IGFBP-3 (hypoxemic, 5.09 \pm 1.25 vs. control, 11.2 \pm 1.08 arbitrary absorbency units per $\mathrm{mm}(\mathrm{Au} \cdot \mathrm{mm}), P$ $<0.01)$, and increase in IGFBP-2 $(0.47 \pm 0.03$ vs. $0.19 \pm 0.13$ Au $\cdot \mathrm{mm}, P<0.05$ ), but no significant downregulation of hepatic GH receptors (hypoxemic, 106.1 \pm 20.1 vs. control, $147.3 \pm 25.9 \mathrm{fmol} / \mathrm{mg}$, NS). Thus, chronic hypoxemia in the newborn is associated with a decrease in IGF-I and IGFBP-3 in the face of normal GH. This suggests peripheral GH unresponsiveness, similar to protein-calorie malnutrition or $\mathbf{G H}$ receptor deficiency dwarfism, but mediated at a level distal to the hepatic GH receptor. (J. Clin. Invest. 1992. 89:1128-1132.) Key words: hypoxia • failure to thrive • somatomedins
\end{abstract}

\section{Introduction}

Growth failure is a frequent and serious complication in infants and children with chronic hypoxemia secondary to cyanotic congenital heart disease (1-4). Whereas recent surgical advances have allowed for early correction or palliation in most cases, many forms of cyanotic congenital heart disease are complex and not readily amenable to repair in early infancy. In this circumstance, surgical repair is usually delayed until the infant reaches a specified weight, yet the adverse effects of chronic hypoxemia on growth make this a difficult goal to achieve. Although there have been several previous investigations to determine the etiology of growth failure during

This work was presented in abstract form at the annual meeting of the Society for Pediatric Research, Washington DC, May, 1989.

Address correspondence and reprint requests to Dr. Daniel Bernstein, Department of Pediatrics, Stanford University, Stanford, CA 94305.

Received for publication 22 July 1991 and in revised form 21 October 1991.

J. Clin. Invest.

(C) The American Society for Clinical Investigation, Inc.

$0021-9738 / 92 / 04 / 1128 / 05 \$ 2.00$

Volume 89, April 1992, 1128-1132 chronic hypoxemia, the exact mechanisms are still not well defined $(5-10)$. Hypermetabolism $(5,6)$, reduced visceral blood flow (11), tissue hypoxemia (12), reduced caloric intake $(1,12)$, abnormalities in digestive enzymology (13-16), and alterations in growth hormone and insulin metabolism $(17,18)$ have been proposed as etiologies. However, previous studies in infants and children with cyanotic congenital heart disease have been complicated by difficulties in controlling for the multiple variables present in the clinical setting $(6,8,19-23)$.

To better determine the mechanisms underlying growth failure during chronic hypoxemia, Teitel and colleagues developed a model of cyanotic congenital heart disease in the newborn lamb (7). These authors determined that chronically hypoxemic lambs grew at one-fourth the rate of their age-matched controls. Using this model, we have previously reported a decrease in both gastrointestinal tract blood flow and intestinal lactase activity during chronic hypoxemia $(11,13)$. The first purpose of the current study was to determine whether chronic hypoxemia during the newborn period is associated with alterations in the endocrine mediators of neonatal growth. These mediators include growth hormone (GH), ${ }^{1}$ which exerts its growth-promoting effects on peripheral tissues through the actions of insulin-like growth factor (IGF-I) (somatomedin). IGF-I is bound in serum to IGF-binding proteins, and IGF-I synthesis in the liver is regulated by the binding of growth hormone to specific GH receptors. Thus, we also sought to determine whether alterations of the growth hormone/somatomedin axis during chronic hypoxemia were related to downregulation of the hepatic growth hormone receptor, or to alterations in the IGF-binding proteins.

\section{Methods}

Surgical preparation. Chronic hypoxemia was produced in 12 newborn lambs, using a model of cyanotic congenital heart disease developed by Teitel and coworkers (7). Briefly, surgery was performed on newborn lambs of mixed western breed during the first week of life. Polyvinyl catheters were inserted via a hind leg pedal artery and vein, and advanced into the descending aorta and inferior vena cava. Under general anesthesia, a thoracotomy was performed in the fourth left intercostal space. Polyvinyl catheters were inserted into the ascending aorta, superior vena cava, right ventricle, pulmonary artery, and left atrium. A Fogarty dilation catheter (model 5 F; Baxter Healthcare Corp., McGaw Park, IL) was inserted via the hind leg pedal vein and advanced by direct visualization into the left atrium. A balloon atrial septostomy was then performed. The atrial septal defect was sized by passing the partially inflated balloon catheter across the defect and additional septostomies were performed, if necessary. Next, an inflatable silicone rubber balloon occluder with polyvinyl tubing was placed around the

1. Abbreviations used in this paper: $\mathrm{AU} \cdot \mathrm{mm}$, arbitrary absorbency units per mm; GH, growth hormone; IGF-I,2, somatomedin, insulinlike growth factor; IGFBP-2,3, IGF-binding protein; TBS, triethanolamine-buffered saline; $\mathrm{VO}_{2}$, total body oxygen consumption. 
main pulmonary artery. This balloon occluder was left deflated during the immediate postoperative period, and in this state was nonrestrictive. All catheters were filled with heparin, plugged, and brought to the skin via a subcutaneous tunnel, and were protected by a zippered vest worn by the lamb. The lambs were then returned to their cages and bottle fed throughout the study period. The intravascular catheters were flushed with saline, and reheparinized daily during the 2-wk study period. Antibiotics (Dual-Pen, Tech America, Kansas City, MO) were given intramuscularly, immediately before each catheter flushing. Intramuscular iron dextran complex (equivalent to $100 \mathrm{mg}$ of elemental iron) was given weekly to avoid the hemodynamic effects of iron deficiency.

Production of chronic hypoxemia. After the lambs recovered for $3 \mathrm{~d}$, hypoxemia was produced by gradually inflating the pulmonary arterial occluder balloon with saline, which partially obstructed the right ventricular outflow tract and induced atrial right-to-left shunting. The details of this gradual inflation procedure have been published previously (7). Aortic oxygen saturation was measured by hemoximeter (model OSM3; Radiometer, Copenhagen, Denmark). By adjusting the degree of balloon inflation, aortic oxygen saturation was decreased to 60 to $74 \%$, and was maintained at this level for $2 \mathrm{wk}$. 10 additional lambs also underwent thoracotomies and placement of intravascular catheters, but did not have atrial septostomies or balloon occluders placed and served as normoxemic controls.

The lambs were bottle fed Land O' Lakes lamb milk replacer, consisting of $39 \%$ carbohydrates, primarily lactose, $24 \%$ protein, and $30 \%$ fat. This formula supplies $0.9 \mathrm{Kcal}$ per $\mathrm{cm}^{3}$. The volume and frequency of feedings were: (a) a maximum of $475 \mathrm{~cm}^{3}$ daily in 6 separate feedings from the first to the third days of life; $(b)$ a maximum of $710 \mathrm{~cm}^{3}$ daily in three feedings up to $2 \mathrm{wk}$, and then ad lib. quantities in three daily feedings afterwards. Daily oral intake and weekly weight gain were recorded. Growth rate was calculated as weight gain (g) per day.

Hormone assays. After 2 wk of hypoxemia in the experimental lambs, and at matched ages in the control lambs, morning fasting blood samples were obtained with the lambs resting quietly in a sling in a temperature controlled room. Plasma levels of growth hormone were determined by radioimmunoassay by Dr. Selna Kaplan at the University of California, San Francisco. Plasma levels of IGF-I and IGF-2 were also determined by radioimmunoassay, as previously described (24). To determine the time course of IGF-1 changes, plasma levels were also obtained in six hypoxemic lambs within $3 \mathrm{~d}$ of the onset of hypoxemia, and compared to three age-matched controls.

Circulating IGF binding proteins. Levels of the circulating IGFbinding proteins IGFBP-3 and IGFBP-2 were measured, as described by Rosenbloom et al. (25). Briefly, serum samples $(2 \mu \mathrm{l})$ were applied to a 4\% stacking gel, and subjected to SDS-PAGE electrophoresis through a $10 \%$ polyacrylamide gel. Prestained molecular weight standards were run in parallel. After electrophoresis overnight under nonreducing conditions at $50 \mathrm{~V}$ per sample, the gels were washed for $15 \mathrm{~min}$ in transfer buffer $(0.025 \mathrm{M}$ Tris $\cdot$ base, $0.192 \mathrm{M}$ glycine, and $20 \%$ methanol). The proteins were then transferred to nitrocellulose membranes by electroblotting, and ligand blotting was performed with ${ }^{125} \mathrm{I}-\mathrm{IGF}-\mathrm{II}$, according to the method of Hossenlopp et al. (26). The nitrocellulose membranes were washed in triethanolamine-buffered saline (TBS) $(0.15 \mathrm{M}$ sodium chloride and $0.01 \mathrm{M}$ Tris $\cdot \mathrm{HCl}$ ) containing $3 \%$ Nonidet P-40 for $30 \mathrm{~min}$ at $4^{\circ} \mathrm{C}$. Nonspecific ${ }^{125}$ I-IGF-II binding was blocked by preincubation in TBS containing $1 \%$ BSA for $2 \mathrm{~h}$, and then in TBS containing $0.1 \%$ Tween 20 for $15 \mathrm{~min}$ at $4^{\circ} \mathrm{C}$. The membranes were then incubated for $20 \mathrm{~h}$ with $10^{6} \mathrm{cpm}$ of ${ }^{125}$ I-IGF-II in $20 \mathrm{ml}$ TBS containing $1 \%$ BSA and $0.1 \%$ Tween. The membranes were then washed with TBS, air dried, and exposed to Kodak X-Omat AR film for $3-5 \mathrm{~d}$ at $-70^{\circ} \mathrm{C}$. The autoradiographs were developed and scanned with a laser densitometer. The relative densities of the bands corresponding to IGFBP-3 and IGFBP-2 were expressed as AU $\cdot \mathrm{mm}$.

Hepatic growth hormone receptors. Hepatic growth hormone receptors were quantitated by a modification of the ovine GH-binding assay described by Freemark et al. (27). Samples of liver were obtained after sacrifice, and frozen at $-70^{\circ} \mathrm{C}$. Tissues $(1-5 \mathrm{~g}$ wet $\mathrm{wt})$ were thawed and homogenized in a Dounce-type homogenizer at $4^{\circ} \mathrm{C}$ in $5 \mathrm{ml}$ homogenization buffer ( $20 \mathrm{mM}$ Hepes, $0.3 \mathrm{M}$ sucrose, $0.1 \mathrm{mM}$ phenylmethylsulfonylfluoride, $2 \mathrm{mM}$ EDTA, and $10 \mu \mathrm{g} / \mathrm{ml}$ leupeptin [to inhibit protease activity], $\mathrm{pH}$ 7.6) and filtered through eight layers of cheesecloth. The filtrate was centrifuged at $1,500 \mathrm{~g}$ for $20 \mathrm{~min}$ at $4^{\circ} \mathrm{C}$. The supernatant was then centrifuged at $11,000 \mathrm{~g}$ for $20 \mathrm{~min}$. This supernatant was finally centrifuged at $100,000 \mathrm{~g}$ for $90 \mathrm{~min}$. The resulting pellet was resuspended in $10 \mathrm{ml}$ assay buffer $(25 \mathrm{mM}$ Tris $\cdot \mathrm{HCl}, 10 \mathrm{mM} \mathrm{MgCl}$, $0.1 \% \mathrm{BSA}, \mathrm{pH} 7.6$ ) and centrifuged for $60 \mathrm{~min}$ at $100,000 \mathrm{~g}$. The pellet was then resuspended in $1.5 \mathrm{ml}$ assay buffer and aliquoted $750 \mu \mathrm{g}$ per assay tube. Membrane protein concentration was determined by the method of Lowry (28).

Ovine growth hormone (NIDDK-oGH-I-5, National Hormone and Pituitary Program, National Institute of Diabetes, Digestive and Kidney Diseases) was radioiodinated with chloramine $T$ by a modification of the method of Hunter and Greenwood (29), as described previously (30). The iodinated hormone had a specific activity of $\sim 3 \mu \mathrm{Ci}$ / $\mu \mathrm{g}$, and was stored at $4^{\circ} \mathrm{C}$ in $0.01 \mathrm{~N} \mathrm{HCl}$ before use in binding assays. Assay tubes (in triplicate) contained $5 \mathrm{nM}^{125} \mathrm{I}-\mathrm{oGH}(\sim 10$-fold higher concentration than the calculated $\left.K_{\mathrm{d}}\right), 500 \mu \mathrm{g}$ liver membrane protein, and buffer (for determination of total binding), or $10 \mu \mathrm{g}$ unlabeled oGH (for determination of nonspecific binding) in a total volume of $500 \mu \mathrm{l}$ assay buffer (described above). Tubes were incubated overnight at $4^{\circ} \mathrm{C}$ and quickly vacuum filtered through glass-fiber filters (GF/C; Whatman Inc., Clifton, NJ) and washed with $20 \mathrm{ml}$ cold assay buffer. The filter-bound radioactivity was counted in a gamma counter. Specific binding was calculated as the total amount of bound radioactivity minus that in the presence of unlabeled hormone. Receptor number was expressed as the amount of specifically bound radioactivity to protein concentration, assuming monoiodination of $\mathrm{GH}$, and a constant ratio of hormone molecules to receptor molecules.

Statistical comparisons were made between hypoxemic and control values with an unpaired Student's $t$ test, and data are shown as the mean $\pm \mathrm{SE}$ of the mean. Statistical significance was considered achieved when $P<0.05$.

\section{Results}

Somatic growth. Lambs in the experimental group grew normally until the onset of hypoxemia, after which they grew at approximately one-third the rate of the controls (Fig. 1).

Growth-mediating hormones. During chronic hypoxemia, plasma levels of IGF-I, the major postnatal somatomedin, were decreased by $43 \%(P=0.01)$ (Fig. 2). Levels of IGF-II, the major fetal somatomedin, were not different from control. Plasma levels of growth hormone tended to be increased in the hypoxemic lambs; however, this difference did not reach statistical significance (Fig. 3). This decrease in IGF-1 probably occurs within the first $72 \mathrm{~h}$ after the onset of hypoxemia, as indicated by early measurements in several lambs (hypoxemic $199 \pm 40$ vs. control, $319 \pm 60 \mathrm{ng} / \mathrm{ml}$ ), although this difference fell short of statistical significance due to the smaller number of subjects.

IGF-binding proteins and hepatic growth hormone receptors. Fig. 4 shows an autoradiograph of a Western ligand blot

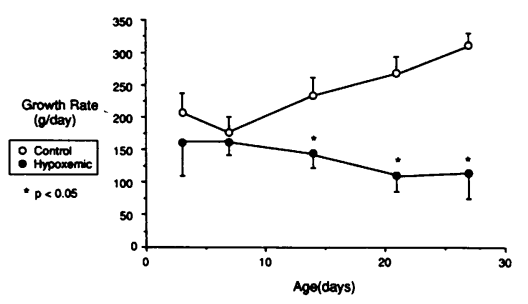

Figure 1. Growth rate compared between chronically hypoxemic and normoxemic control lambs. ${ }^{*} P<0.05$ by Student's $t$ test. 


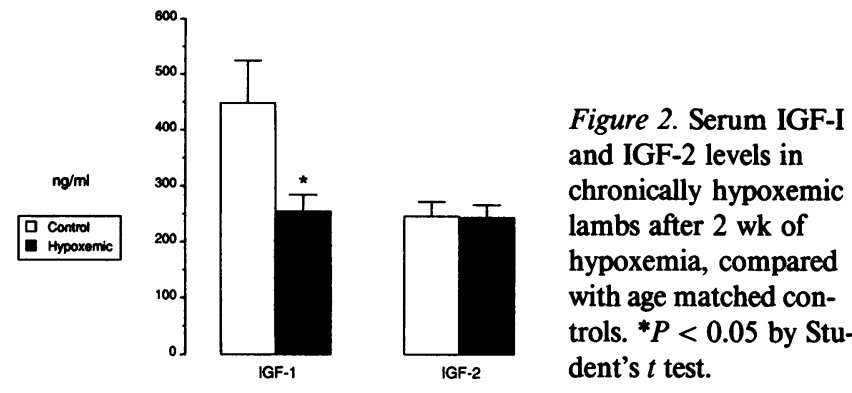

comparing levels of IGF-binding proteins in control and hypoxemic lambs. Densitometric analysis demonstrated that plasma levels of IGFBP-3 were decreased by $55 \%$ in the hypoxemic lambs compared to controls $(P<0.01)$ (Fig. 5). Conversely, levels of IGFBP-2 were increased in the hypoxemic lambs by $154 \%(P<0.05)$. Although there was a tendency for growth hormone receptors to be decreased in the hypoxemic lambs, this difference did not reach statistical significance (Fig. 6).

\section{Discussion}

Growth failure is a serious complication in infants and children with chronic hypoxemia secondary to cyanotic congenital heart disease (1-4). Although growth failure may not correlate directly with the degree of hypoxemia, long-standing hypoxemia is associated with retarded skeletal maturation and pubertal delay $(2,4)$. Palliative surgery alone may not result in inereased growth despite improvement in systemic oxygenation, as long as systemic oxygen saturation is still below normal (31). The exact mechanisms of this growth failure are still not well defined, and it is likely that the etiology is multifactorial. Increased cardiorespiratory work may result in an increase in caloric requirements $(5,6)$. Although total body oxygen consumption is normal during chronic hypoxemia (5-8), there may be an increase in cardiorespiratory oxygen consumption, counterbalanced by a decrease in oxygen consumption directed towards growth $(9,10)$. Reduced peripheral blood flow could also lead to alterations in growth. Cardiac output is redistributed during chronic hypoxemia, with decreases in gastrointestinal tract and carcass blood flows and oxygen delivery (11). Tissue hypoxemia may directly affect DNA, protein and collagen synthesis $(11,32)$, and enhance synthesis of oxygen-regulated proteins (33).

The results of the current study demonstrate one potential mechanism for the growth failure associated with cyanotic congenital heart disease. Our results show that in lambs with chronic hypoxemia secondary to an intracardiac right-to-left shunt, levels of IGF-I, one of the major endocrine regulators of postnatal growth, are decreased by almost half. Levels of growth hormone tended to be slightly greater in the hypoxemic lambs, although this difference did not reach statistical significance. There have been several previous clinical studies of growth-regulating hormones in patients with cyanotic congenital heart disease. Growth hormone levels are as much as sixfold greater in children with cyanotic heart disease, compared to controls and to children with acyanotic heart disease (23). Growth hormone levels are also elevated in high altitude dwellers with chronic hypobaric hypoxemia (34). Although IGF levels have not been previously measured in patients with cyanotic congenital heart disease, abnormalities of insulin re- lease have been demonstrated $(17,18)$, and insulin plays a significant role in the control of IGF-I production (10). Our finding of decreased IGF-I in association with normal levels of growth hormone is partially consistent with the findings of previous studies during other chronic stresses. In children with protein-calorie malnutrition, an inverse relationship between decreased IGF-I and elevated GH levels has been demonstrated, suggesting a block in synthesis or release of IGF (35). In patients with insulin-dependent diabetes and the Mauriac syndrome, there is a similar decrease in IGF and increase in GH (10). It has been proposed that in these conditions of chronic stress, the elevated GH acts to preserve body protein and enhance fat-based metabolism, whereas the low level of IGF would divert metabolic energy away from growth (10). Although total body oxygen consumption $\left(\mathrm{VO}_{2}\right)$ in our lambs (7) and in chronically hypoxemic infants (8) is not different from control levels, we speculate that a decrease in the component of $\mathrm{VO}_{2}$ directed towards growth may be counterbalanced by an increase in cardiorespiratory $\mathrm{Vo}_{2}(7,10)$.

Our results also suggest that the decrease in IGF-I cannot be explained entirely by a downregulation of hepatic GH receptors. This is in contrast to other clinical conditions in which IGF is decreased and GH elevated. In GH receptor deficiency dwarfism, the decrease in IGF is secondary to a genetic abnormality of hepatic growth hormone receptors $(25,36)$, and in experimental models of protein-calorie malnutrition, the decrease in IGF appears to be secondary to a downregulation of these receptors $(37,38)$. Our results indicate that the decrease in IGF-I during chronic hypoxemia appears to be mediated at a level distal to the GH receptor, although it is possible that with a larger number of animals the trend toward receptor downregulation would have reached statistical significance. Chronic hypoxemia could have a direct effect on transcription of IGF mRNA, similar to its effect on transcription of other proteins, such as the $\beta$-adrenergic receptor (39). Alternatively, this effect of chronic hypoxemia may be mediated through alterations in a second messenger, such as cAMP. We have previously shown that chronic hypoxemia decreases CAMP generation mediated through the $\beta$-adrenergic receptor (40), and others have shown that IGF-binding protein production is stimulated by agents such as forskolin, glucagon, and theophylline, which increase intracellular levels of cAMP (41). Our finding of decreased IGFBP-3 and increased IGFBP-2 during chronic hypoxemia is also consistent with the results of a previous study demonstrating a similar inverse relationship between the levels of

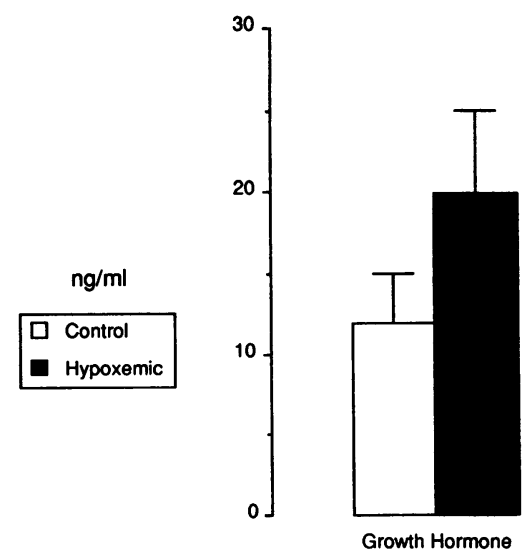

Figure 3. Comparison of plasma growth hormone between chronically hypoxemic and control lambs. $P=\mathrm{NS}$ by Student's $t$ test. 


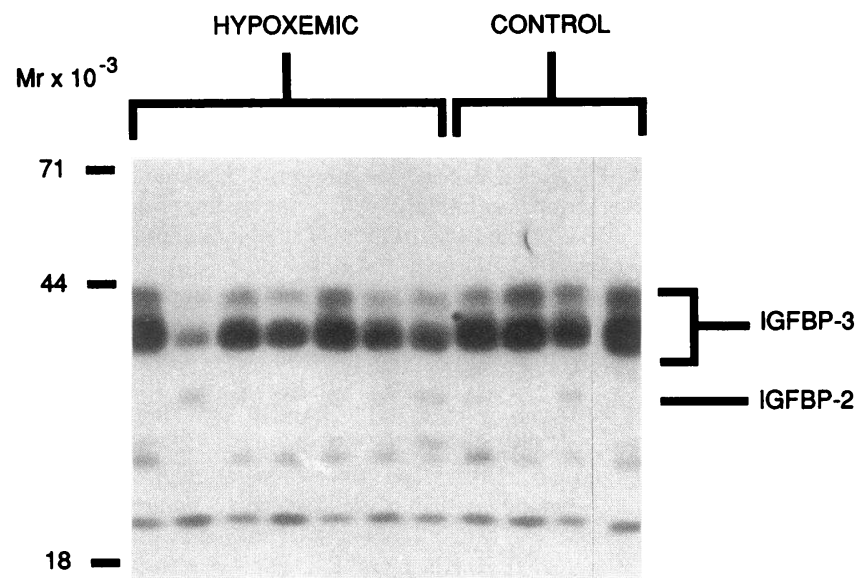

Figure 4. Autoradiograph of a Western blot comparing levels of IGF-binding proteins in control and hypoxemic lambs (see Methods for details. All samples were run on the same gel which was cut once to group all controls and hypoxemics together.).

these two binding proteins in patients with $\mathrm{GH}$ receptor deficiency (25).

It is possible that the decrease in IGF-I we have described in this model is secondary to alterations in nutrition, rather than directly to hypoxemia. Although oral intake is similar in chronically hypoxemic lambs and normoxemic controls, activity of lactase, the principal digestive enzyme for carbohydrates in the newborn intestine, is substantially reduced (13). However, previous studies in the rat have shown that the growth failure encountered during chronic hypoxemia cannot be attributed to alterations in nutrition alone (12), and unlike in chronic malnutrition, where cell size is decreased, chronic hypoxemia results in a decrease in cell number (21). Circulating inhibitors of IGF activity have been demonstrated in patients with proteincalorie malnutrition and diabetes $(10,35)$. These inhibitors interfere with both peripheral IGF action and IGF feedback inhibition of GH release (10). However, the decrease in IGF-I described in the current study was presumably independent of possible serum inhibitors, because IGF was assayed by radioimmunoassay after size-separation gel chromatography, rather than by bioassay.

Thyroid hormone also contributes significantly to postnatal growth. Previous studies in hypoxemic infants with chronic respiratory disease have demonstrated either decreased (42) or normal (37) levels of thyroid hormones. Our previous demonstration that levels of T3 and Free T4 in chronically hypoxemic lambs are not different from control (40) does not support a role for thyroid hormone alterations in this model of cyanotic congenital heart disease.

This study also does not attempt to isolate the effects of chronic hypoxemia from the additional hemodynamic, hema-

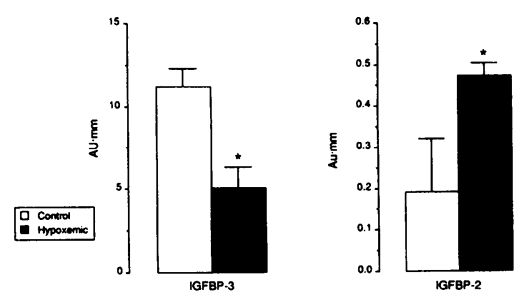

Figure 5. Comparison of plasma IGF-binding proteins IGFBP-2 and IGFBP-3 between chronically hypoxemic and control lambs. ${ }^{*} P$ $<0.05$ by Student's $t$ test.

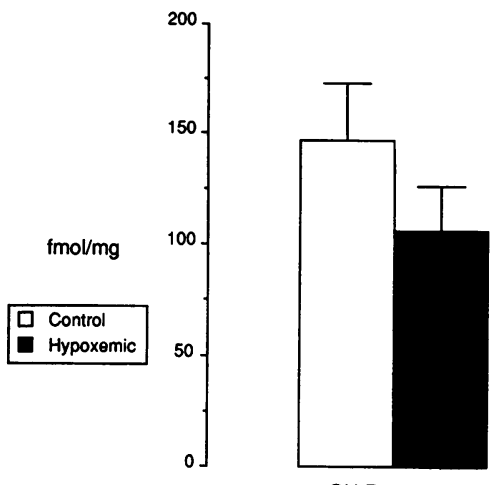

GH Receptors
Figure 6. Comparison of hepatic growth hormone receptor density between chronically hypoxemic and control lambs. $P$ $=$ NS by Student's $t$ test. tologic, and neurohumoral alterations present secondary to right ventricular outflow tract obstruction and atrial right-toleft shunting. It is possible that passive congestion could have altered hepatic synthesis of IGF-I. However, we have previously shown that central venous pressures are not altered in chronically hypoxemic lambs, and that there is no generalized decrease in hepatic protein synthesis, as determined by serum protein measurements (7). Finally, our model is also potentially limited in that it does not produce in utero hemodynamic alterations or hypoxemia immediately after birth, as would be present in many infants with cyanotic congenital heart disease. We acknowledge this limitation in our model, however, recognizing that there are many cyanotic congenital lesions which are not associated with severe hypoxemia at birth, and in which progressive hypoxemia develops only over the first few months of life.

In summary, we have demonstrated decreased levels of IGF-I associated with growth failure in a model of cyanotic congenital heart disease in the newborn lamb. This decrease in IGF-I is associated with normal to slightly elevated levels of growth hormone. Unlike protein-calorie malnutrition, the mechanism for this decrease in IGF-I is not related to a significant downregulation of the hepatic growth hormone receptor. We speculate that the decrease in IGF-I may be secondary to alterations in signal transduction distal to the growth hormone receptor binding site. Alternatively, chronic hypoxemia may directly modulate transcriptional, translational, or posttranslational regulation of IGF-I, as it does for other proteins (39).

\section{Acknowledgments}

The authors wish to acknowledge the assistance of Dr. Selna Kaplan of the University of California, San Francisco, who performed the plasma ovine growth hormone assays, and the technical assistance of Ms. Rebecca Peters and Dr. Hung Pham.

Supported by grants from the National Institutes of Health (HL38741 and DK-28229) and by a Grant-in-Aid from the American Heart Association, California Affiliate.

\section{References}

1. Elliott, D., and D. Cheek. 1968. Muscle and liver cell growth in rats with hypoxia and reduced nutrition. In Human Growth. D. Cheek, editor. Lea and Febiger, Philadelphia. 326-336.

2. Linde, L., O. Dunn, R. Schireson, and B. Rasof. 1967. Growth in children with congenital heart disease. J. Pediatr. 70:413-419.

3. Gingell, R., D. Pieroni, and M. Hornung. 1981. Growth problems asso- 
ciated with congenital heart disease in infancy. In Textbook of Gastroenterology and Nutrition in Infancy. E. Lebenthal, editor. Raven Press, New York. 853-860.

4. Danilowicz, D. 1973. Delay in bone age in children with cyanotic congenital heart disease. Radiology. 108:655-658.

5. Menon, G., and E. Poskitt. 1985. Why does congenital heart disease cause failure to thrive? Arch. Dis. Child. 60:1134-1139.

6. Sondheimer, J., and J. Hamilton. 1978. Intestinal function in infants with severe congenital heart disease. J. Pediatr. 92:572-578.

7. Teitel, D., D. Sidi, D. Bernstein, M. Heymann, and A. Rudolph. 1985. Chronic hypoxemia in the newborn lamb: cardiovascular, hematopoietic, and growth adaptations. Pediatr. Res. 19:1004-1010.

8. Huse, D., R. Feldt, R. Nelson, and L. Novak. 1975. Infants with congenital heart disease. Food intake, body weight, and energy metabolism. Am. J. Dis. Child. 129:65-69.

9. Sidi, D., J. Kuipers, D. Teitel, M. Heymann, and A. Rudolph. 1983. Developmental changes in oxygenation and circulatory responses to hypoxemia in lambs. Am. J. Physiol. 245:H674-H682.

10. Phillips, L. 1986. Nutrition, somatomedins, and the brain. Metab. Clin. Exp. 35:78-87.

11. Bernstein, D., D. Teitel, D. Sidi, M. Heymann, and A. Rudolph. 1987. Redistribution of regional blood flow and oxygen delivery in experimental cyanotic congenital heart disease. Pediatr. Res. 22:389-393.

12. Cheek, D., J. Graystone, and R. Rowe. 1969. Hypoxia and malnutrition in newborn rats: effects on RNA, DNA, and protein in tissues. Am. J. Physiol. 217:642-645.

13. Bernstein, D., J. Bell, L. Kwong, and R. Castillo. 1992. Alterations in postnatal intestinal function during chronic hypoxemia. Pediatr. Res. In press.

14. Lifshitz, F., R. Pergolizzi, A. Lipkin, S. Teichberg, and R. Wapnir. 1976. Alterations in intestinal transport and (Na-K) ATPase in hypoxia. Fed. Proc. 35:464.

15. Lifshitz, F., R. Wapnir, R. Pergolizzi, and S. Teichberg. 1976. Intestinal function alterations induced by hypoxia. Gastroenterology. 70:908.

16. Lluch, M., and F. Ponz. 1962. Influencia de la anoxia sobre la absorción activa de azúcares por el intestino. Rev. Esp. Fisiol. 18:157-162.

17. Hait, G., M. Corpus, F. Lamarre, S. Yuan, J. Kypson, and G. Chen. 1972 Alteration of glucose and insulin metabolism in congenital heart disease. Circulation. 46:333-346.

18. Gács, G., E. Kun, and K. Berend. 1973. Hypoglycemia in infants and children with cyanotic congenital heart disease. Acta Pediat. Acad. Sci. Hung. 14:105-111.

19. Vanderhoof, J., P. Hofschire, M. Baluff, J. Guest, N. Murray, W. Pinsky, J. Kugler, and D. Antonson. 1982. Continuous enteral feedings. Am. J. Dis. Child. 136:825-827.

20. Strangway, A., R. Fowler, K. Cunningham, and J. Hamilton. 1976. Diet and growth in congenital heart disease. Pediatrics. 57:75-86.

21. Naeye, R. 1966. Organ and cellular development in mice growing at simulated high altitude. Lab. Invest. 15:700-706.

22. Tejani, N., F. Lifshitz, and R. Harper. 1979. The response to an oral glucose load during convalescence from hypoxia in newborn infants. J. Pediatr. 94:792-796.

23. Fahrer, M., L. Gruñeiro, M. Rivarola, and C. Bergadá. 1974. Levels of plasma growth hormone in children with congenital heart disease. Acta Endocrinol. 77:451-459.

24. Soliman, A., A. Hassan, M. Aref, R. Hintz, R. Rosenfeld, and A. Rogol 1986. Serum insulin-like growth factors I and II concentrations and growth hormone and insulin responses to arginine infusion in children with protein-energy malnutrition before and after nutritional rehabilitation. Pediatr. Res. 20:11221130.

25. Rosenbloom, A., J. Guevara Aguirre, R. Rosenfeld, and P. Fielder. 1990 The little women of Loja-Growth hormone-receptor deficiency in an inbred population of southern Ecuador. N. Engl. J. Med. 323:1367-1374.

26. Hossenlopp, P., D. Seurin, B. Segovia-Quinson, S. Hardouin, and M Binoux. 1986. Analysis of serum insulin-like growth factor binding proteins using Western blotting: use of the method for titration of the binding proteins and competitive binding studies. Anal. Biochem. 154:139-143.

27. Freemark, M., M. Comer, and G. Korner. 1988. Differential Solubilization of Placental lactogen (PL)- and growth hormone-binding sites: further evidence for a unique PL receptor in fetal and maternal liver. Endocrinology. 122:2771-2779.

28. Lowry, O., N. Rosebrough, A. Farr, and R. Randall. 1951. Protein measurement with the Folin phenol reagent. J. Biol. Chem. 193:265-275.

29. Hunter, W. M., and E. C. Greenwood. 1962. Preparation of iodine-131 labeled human growth hormone of high specific activity. Nature (Lond.). 194:495-498.

30. Rosenfeld, R., B. Aggarwal, R. Hintz, and L. Dolar. 1982. Recombinant DNA-derived methionyl human growth hormone is similar in membrane binding properties to human pituitary growth hormone. Biochem. Biophysiol. Res. Comm. 106:202-209.

31. Baum, D., R. Beck, and W. Haskell. 1983. Growth and tissue abnormalities in young people with cyanotic congenital heart disease receiving systemic pulmonary artery shunts. Am. J. Cardiol. 52:349-352.

32. Stavenow, L., and A. Berg. 1987. Effects of hypoxia and other injurious stimuli on collagen secretion and intracellular growth stimulating activity of bovine aortic smooth muscle cells in culture. Artery. 14:198-208.

33. Heacock, C., and R. Sutherland. 1986. Induction characteristics of oxygen regulated proteins. Int. J. Radiat. Oncol. Biol. Phys. 12:1287-1290.

34. Raynaud, J., L. Drouet, J. Martineaud, J. Bordachar, J. Coudert, and J. Durand. 1981. Time course of plasma growth hormone during exercise in humans at altitude. J. Appl. Physiol. 50:229-233.

35. Hintz, R., R. Suskind, K. Amatayakul, O. Thanangkul, and R. Olson. 1978. Plasma somatomedin and growth hormone values in children with proteincalorie malnutrition. J. Pediatr. 92:153-156.

36. Eshet, R., Z. Laron, A. Pertzelan, R. Arnon, and M. Dintzman. 1984. Defect of human growth hormone receptors in the liver of two patients with Laron-type dwarfism. Isr. J. Med. Sci. 20:8-11.

37. Klein, A., B. Foley, T. Foley, H. MacDonald, and D. Fisher. 1981. Thyroid function studies in cord blood from premature infants with and without RDS. J. Pediatr. 98:818-820.

38. Postal-Vinay, M., E. Cohen-Tough, and J. Charrier. 1982. Growth hormone receptors in rat liver membranes: effects of fasting and refeeding and correlation with plasma somatomedin activity. Molec. Cell. Endocrinol. 28:657-669.

39. Bernstein, D., R. Doshi, S. Huang, and E. Strandness. 1991. Transcriptional regulation of left ventricular $\beta$-adrenergic receptors during chronic hypoxia. Pediatr. Res. 29:15A. (Abstr.).

40. Bernstein, D., E. Voss, S. Huang, R. Doshi, and C. Crane. 1990. Differential regulation of right and left ventricular $\beta$-adrenergic receptors in experimental cyanotic heart disease in newborn lambs. J. Clin. Invest. 85:69-74.

41. Lewitt, M., and R. Baxter. 1989. Regulation of growth hormone-independent insulin-like growth factor-binding protein (BP-28) in cultured human fetal liver explants. J. Clin. Endocrinol. Metab. 69:246-252.

42. Moshang, T., K. Chance, M. Kaplan, R. Utiger, and O. Takahashi. 1980. Effects of hypoxia on thyroid function tests. J. Pediatr. 97:602-604. 